\title{
Chamaegastrodia poilanei - an interesting mycoheterotrophic orchid from India
}

\author{
Tiwari U.L. ${ }^{1}$, Bhattacharjee A. ${ }^{1}$, Tian H.Z. ${ }^{2}$, Yukawa T. ${ }^{3}$ \& P. Kumar ${ }^{4 *}$ \\ ${ }^{1}$ Botanical Survey of India, Central National Herbarium, Botanic Garden, Howrah - 711 103, West Bengal, India \\ ${ }^{2}$ School of Life Sciences, East China Normal University, Shanghai - 200 241, China \\ ${ }^{3}$ Tsukuba Botanical Garden, National Museum of Nature and Science, Tsukuba, Ibaraki, Japan \\ ${ }^{4}$ Kadoorie Farm and Botanic Garden, Lam Kam Road, Lam Tsuen, Tai Po, New Territories, Hong Kong S.A.R., P.R. China \\ *E-mail: pkumar@kfbg.org
}

\begin{abstract}
Chamaegastrodia poilanei (Gagnep.) Seidenf. is reported from Arunachal Pradesh, India, with a detailed description, notes on taxonomy, provision of its differentiating characters from C. asraoa (J.Joseph \& Abbar.) Seidenf. \& A.N.Rao, supplemented with a colour photographic plate, and a conservation assessment.
\end{abstract}

Keywords: Arunachal Pradesh, Mycoheterotrophic, Odontochilus asraoa.

\section{Introduction}

Chamaegastrodia Makino \& F.Maek. (Maekawa, $1935)$ is a genus of terrestrial, mycoheterotrophic orchids comprising five species (Pridgeon et al., 2003) distributed in Bhutan, China, Japan, Korea, Myanmar, Nepal, Thailand and Vietnam (Govaerts et al., 2021). The generic placement of the members of Chamaegastrodia has been a subject of controversy among taxonomists and orchidologists for a long time.

Seidenfaden (1978) treated Evrardia Gagnep. (Gagnepain, 1932) as a valid genus, without being aware of the placement of this genus under Hetaeria Lindl. by Tang and Wang (1951) and subsequently under Chamaegastrodia by Brieger (1974). The name, Evrardia Gagnep. is a later homonym of Evrardia Adans. belonging to family Anacardiaceae (Adanson, 1763), hence a new

Received: 22.09.2021; Revised \& Accepted: 27.09.2021

Published Online: 16.10 .2021 name Evrardianthe Rauschert was proposed by Rauschert (1983). Later, Seidenfaden (1994) transferred the genus Evrardia (Orchidaceae) to Chamaegastrodia. Ormerod (2002) transferred Chamaegastrodia to Odontochilus Blume based on the similarity in some characters of the column, claiming that the members of the former are just mycoheterotrophic forms of the latter and accordingly he created three sections under the genus: Odontochilus sect. Odontochilus (column with confluent to connate stigmatic lobes), sect. Evrardia (column twisted with separate stigmatic lobes), and sect. Physopus (column not twisted but with separate stigmatic lobes). Ormerod (2002) also claimed that the placement of Evrardia in Chamaegastrodia is incorrect because "the latter differs in its column wings, which are apical on the lateral margins of the column, whereas they are ventral and intra-marginal in the former as in Odontochilus". Bhattacharjee and Chowdhery (2018) followed Seidenfaden's (1978) concept and treated Chamaegastrodia as a distinct genus in their work, due to its mycoheterotrophic habit with a leafless stem, non-resupinate flowers and column wings situated on the lower apical margin of the column, which is followed here. We provide a detailed taxonomic account of Chamaegastrodia poilanei (Gagnep.) Seidenf. \& A.N.Rao based on literature (including protologue), specimens (including types), and freshly collected plants from Arunachal Pradesh, northeast India by the first author (ULT). A molecular study on the entire 
genus Chamaegastrodia and Odontochilus is needed to confirm the placement of C. poilanei. We also provide information on the distribution of the species, phenology, habit and a conservation assessment.

\section{Taxonomic Treatment}

Chamaegastrodia poilanei (Gagnep.) Seidenf. \& A.N.Rao, Nordic J. Bot. 14: 297. 1994. Evrardia poilanei Gagnep., Bull. Mus. Natl. Hist. Nat., sér. 2, 4: 596. 1932. Hetaeria poilanei (Gagnep.) Tang \& F.T.Wang, Acta Phytotax. Sin. 1: 71. 1951. Evrardianthe poilanei (Gagnep.) Rauschert, Feddes Repert. 94: 433. 1983. Evrardiana poilanei (Gagnep.) Aver., Bot. Zhurn. (Moscow \& Leningrad) 73: 432. 1988. Odontochilus poilanei (Gagnep.) Ormerod, Lindleyana 17: 225. 2002. Syntypes: VIETNAM, Annam, Dalat, 15.11.1924, F. Evrard 1807 (P [P00345030!]); Kontum, Montagne Mam Ray, 02.09.1930, E. Poilane 18204 (P [P00345029!]).

Fig. 1

Plants mycoheterophic, erect, up to $20 \mathrm{~cm}$ tall. Rhizome creeping, up to $5 \mathrm{~cm}$ long, terete. Stems erect, dark red, leafless but covered with scaly, red, overlapping sheaths. Rachis terete, up to $7 \mathrm{~cm}$ long, pubescent, flowers clustered towards apex. Flowers up to 10 , non-resupinate, up to $1.5 \mathrm{~cm}$ wide and $1.5 \mathrm{~cm}$ long. Pedicel and ovary red, densely pubescent, fusiform. Bracts red, elongate-ovate, acute, as long as ovary, $1.4-0.8 \mathrm{~cm}$ long, $0.4-0.6$ $\mathrm{cm}$ wide, sparsely hairy towards the lower $1 / 3^{\text {rd }}$ on the outer side. Dorsal sepal pubescent on outer surface, forming a hood with the lateral sepals over the column, $0.6-0.7 \mathrm{~cm}$ long, up to $0.5 \mathrm{~cm}$ wide, triangular, acute. Lateral sepals red, obliquely falcate, $0.4-0.5 \mathrm{~cm}$ wide, up to $1.0 \mathrm{~cm}$ long, acute, sparsely pubescent on outer surface, slightly rough on shorter margin. Petals red with transparent or white bands, ovate, spreading, sickle-shaped, 0.6$0.7 \mathrm{~cm}$ long, up to $0.2 \mathrm{~cm}$ wide, acute. Labellum in shades of yellow and red, Y- or T-shaped, 1.7-1.9 $\mathrm{cm}$ long; hypochile saccate, up to $0.2 \mathrm{~cm}$ wide with a sessile globular calli at the base on each side; mesochile $0.6-0.8 \mathrm{~cm}$ long, with flanges, $0.1-0.3$ cm long, not deeply but irregularly laciniate; epichile 2-lobed, V-shaped, 0.2-1.7 cm wide, up to $0.4 \mathrm{~cm}$ long; lobules diverging laterally almost at right angles, $0.5 \mathrm{~cm}$ wide in middle to up to 1.0 $\mathrm{cm}$ wide towards edge, minutely papillose, slightly concave towards the centre bearing lacerate margin towards the edge with irregular lacinia, the inner most segment of the lobule-margin (i.e., the terminal lobules of epichile wings) much longer than others, up to $0.7 \mathrm{~cm}$ long, $0.1-0.2 \mathrm{~cm}$ wide. Column short, stout, with lamellate wings; pollinia lobes ovate, up to $0.3 \mathrm{~cm}$ long, acuminate; rostellum erect, 2-lobed, $2.0-2.5 \mathrm{~mm}$ long.

Flowering: Flowering from August to October, fruiting not observed.

Habitat: In subtropical moist broadleaved evergreen forests at elevations between 1200-1600 m, under the shade of Bambusa multiplex (Lour.) Raeusch. ex Schult.f., Dendrocalamus hamiltonii Nees \& Arn. ex Munro, Drepanostachyum intermedium (Munro) Keng f. (all Poaceae), Saurauia napaulensis DC. (Actinidiaceae) etc. Being a mycoheterotropic orchid, it may be dependent on a specific mycorrhizal fungus and therefore is habitat limited (Bidartondo, 2005).

Distribution: Bhutan, China, India, Myanmar, Nepal, Taiwan, Thailand and Vietnam (Govaerts et al., 2021).

Specimens examined: CHINA, Hainan, Lingshui, Baishuiling under evergreen broad-leaved forest by the side of valley, $700 \mathrm{~m}, 26.07 .2006, A . H u, L$ Lin \& H.Z. Tian 140 (IBSC); Tibet, Motuo, near old Motuo district, 1000 m, 23.08.1974, Qing Zang team 74-4455 (PE [PE00271146, PE00271147], KUN [KUN0019486]); Yunnan, Hekou County, Hekou city, the forest behind the fourth Dujiaotang, 1810 m, 14.08.1953, W. Liu 622 (PE [PE00271136]). INDIA, Arunachal Pradesh, East Kameng district, Jayang Baggang village, 25.08.2018, U.L. Tiwari 40665; Pakhe Kessang, 30.08.2018, U.L. Tiwari 40758 (ARUN). MYANMAR. National Kandawgyi Garden, Pine forest, P.U. Lwin \& S. Lwin s.n. (TNS). 


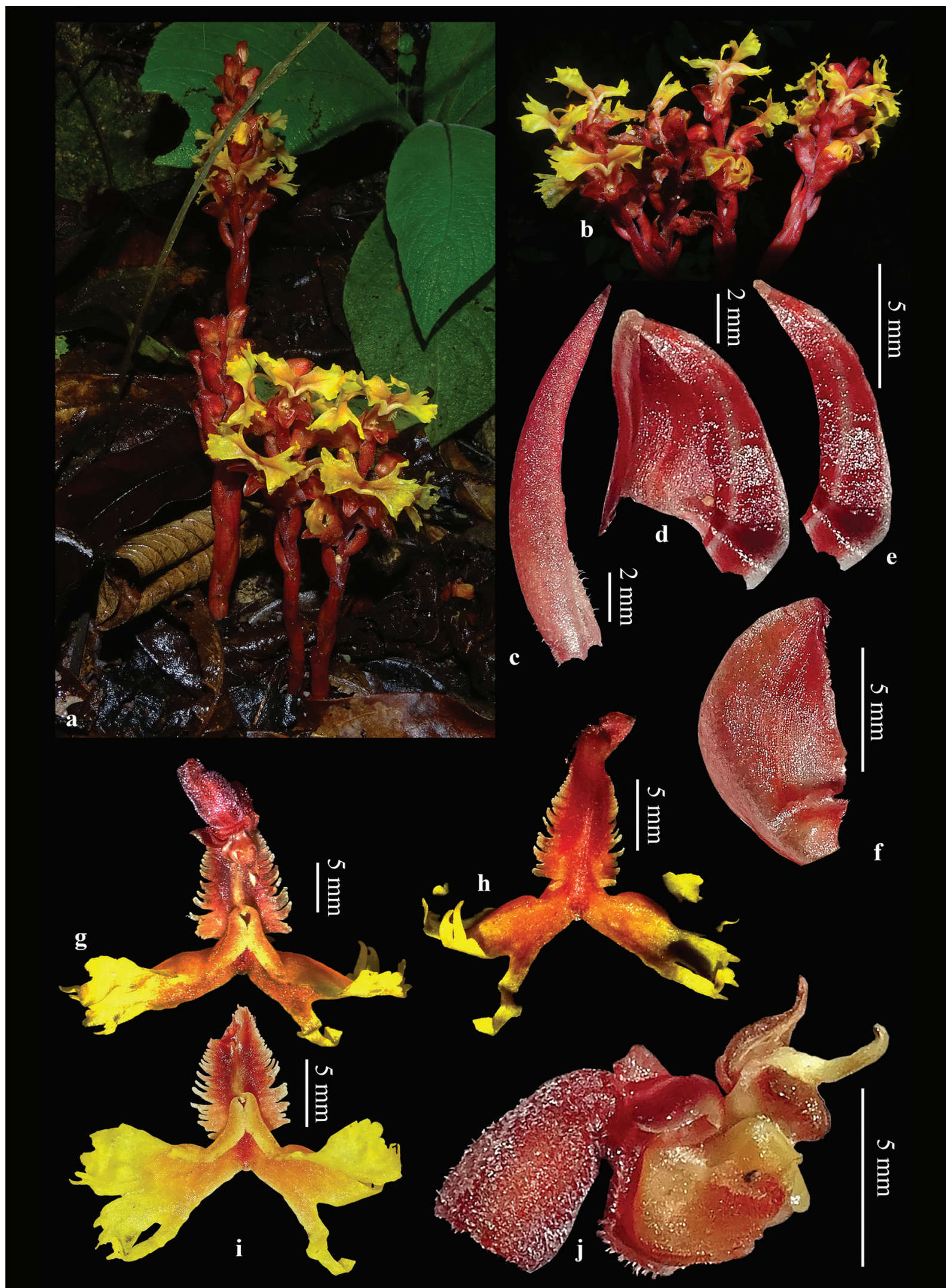

Fig. 1. Chamaegastrodia poilanei (Gagnep.) Seidenf. \&A.N.Rao: a. Plant; b. Close-up of inflorescence; c. Bract; d. Dorsal sepal with petals; e. Petal; f. Lateral sepal; g. Labellum with ovary-top view; h. Labellum-ventral view; i. Labellum-dorsal view; j. Column with pollinarium and anther cap-side view (from U.L. Tiwari 40665; photos by U.L. Tiwari). 
TAIWAN. Nantou County, Lugu Township, 19.08.2013, C.K. Yang \& H.T. Yeh 1890 (TNUdetailed sketch and coloured plates seen).

Conservation assessment: Chamaegastrodia poilanei is widely distributed from northeast India, Bhutan, and China to Japan and Taiwan in the East, and to Myanmar, Thailand and Vietnam in the South (Govaerts et al., 2021). The species is already believed to be extinct in Japan and there are less than ten plants known to occur at a single locality in Taiwan (Yang et al. 2014). Accordingly the species was assessed as Critically Endangered in Taiwan by Yang et al. (2014). It is likely that this species is yet to be discovered in adjacent areas in Cambodia Laos and parts of south China with suitable habitat. Being a mycoheterotrophic orchid, it is assumed that this species is very habitat specific (Jacquemyn et al., 2016). As such this species does not face any poaching threat like most of the other jewel orchids do (i.e., members of subtribe Goodyerinae). Although habitat loss could be one of the potential threats for this species which has such widespread distribution range, not enough information is available from the major part of its distribution range to come to any appropriate conclusion. Hence, with available information this species can only be assessed as DD based on IUCN (2019) guidelines.

Notes: Chamaegastrodia poilanei was originally described as Evrardia poilanei from Vietnam and has subsequently been found in Bhutan, China, Japan, Myanmar, Nepal, Taiwan, Thailand (Govaerts et al., 2021) and in Arunachal Pradesh, India (this study). While the protologue lacks line drawings, there are some detailed line drawings on the syntypes (F. Evrard 1807, P [P00345030]). A few of these drawings were later reproduced by Gagnepain (1934). In the protologue, the labellum was mentioned as having a denticulate margin, which corresponds with the sketch on P00345030 as well as with the description provided by Gagnepain (1934). The same illustration was used by Seidenfaden (1978: fig. 33). It was referenced by Joseph and Abbareddy (1985) when they described Evrardia asraoa J. Joseph \& Abbar. [= C. asraoa (J. Joseph \& Abbar.) Seidenf. \& A.N.Rao] from Meghalaya in northeast India, which is very closely allied to $C$. poilanei. The new species was differentiated from C. poilanei on the basis of absence of elongate terminal lobules of epichile wings ( $v s$. presence of long terminal lobules of epichile wings in C. poilanei), presence of deeply irregular erose mesochile flanges (vs. irregularly dented mesochile flanges in C. poilanei), and the presence of simple rostellar process ( $v s$. forked rostellar process in C. poilanei). However, the description of the mesochile flanges of C. asraoa as irregularly denticulate according to the protologue may be an artifact of the poorly preserved herbarium specimen. Chen et al. (2009) described C. poilanei (as Odontochilus poilanei) with bifurcate rostellar processes, two horn-like, divergent, V-shaped lacunae at the apex of the epichile and narrow, irregularly erose-crenulate flanges on the mesochile.

Freshly collected plants (U.L. Tiwari 40665, 40758) have distinct terminal lobules on the epichile but the mesochile flanges are deeply and irregularly erose (like that of $C$. asraoa) and the rostellar processes are bifurcated lying parallel to one another (V-shaped in protologue). Although the presence of deeply erose versus irregularly denticulate flanges can be an artifact or variation, the presence and absence of terminal lobules on the epichile of the labellum makes C. asraoa distinct from C. poilanei. According to the protologue of C. asraoa the rostellum is simple, i.e., not bifurcated like that of C. poilanei. Since its type collection, C. asraoa has not be recollected until now and due to the lack of workable material of C. asraoa it could not be verified whether the rostellum is simple throughout its flowering stage or it is so in less mature stage of flowers only.

Xu et al. (2011) presented an image under the name O. poilanei, but the labellum is lacking terminal 
lobules and hence this may be a misidentification and it could be C. asraoa. Chamaegastrodia poilanei and C. asraoa were also reported from Bhutan (Dalström et al., 2013). However, from the image provided in this publication, it is not possible to confirm the plant's identity. Swami (2016, 2017) provided a photo of a pale yellow plant identified as O. asraoa on the cover of his book, 'Orchids of Ziro'. The image clearly shows the presence of terminal lobules on the epichile, which points towards two facts: firstly, that the identification of this image is wrong (and the plant is in fact $C$. poilanei), and secondly, that C. poilanei occurs in two colour forms, one being the more typical yellow and red colour form commonly reported under this name as also in this manuscript, and the second being a pale yellow form (with no red markings), as on the cover of 'Orchids of Ziro'. Swami $(2016,2017)$ reported C. poilanei (as Odontochilus poilanei) from Arunachal Pradesh, but due to lack of any voucher specimen, Bhattacharjee and Chowdhery (2018) treated this report as doubtful. However, the present collections from East Kameng district of Arunachal Pradesh by the first author confirm its occurrence in India.

\section{Acknowledgements}

The authors are grateful to Dr. P. Singh, Director (retd.) and Dr. A. Pathak, (ex-Director in charge); Dr. A.A. Mao, Director, Botanical Survey of India (BSI), Kolkata; to Dr. V.K. Rawat HOO, BSI APRC, Itanagar for all support and logistics.

\section{Literature Cited}

ADANSON M. 1763. Families des plantes. Vincent, Paris.

BHATTACHARJEE A. \& H.J. CHOWDHERY 2018. Orchidaceae: Orchidoideae: Cranichideae: Subtribe Goodyerinae. In: SINGH P. (ed.), Fascicles of Flora of India, Volume 28. Botanical Survey of India, Kolkata, p. 285.

BIDARTONDO M.I. 2005. The evolutionary ecology of mycoheterotrophy. New Phytologist 167: 335-352. https://doi.org/10.1111/j.1469-8137.2005.01429.x

BRIEGER F.G. 1974. Unterfamilie: Neottioideae. In: BRIEGER G.F., MAATSCH R. \& K. SENGHAS (eds.), Die Orchideen, Third Edition. Paul Parey, Berlin, pp. 254-358.

CHEN S.C., GALE S.W., CRIBB P.J. \& P. ORMEROD. 2009. Odontochilus. In: WU Z.Y., RAVEN P.H. \& D.Y. HONG (eds.), Flora of China, Volume 25. Science Press, Beijing, and Missouri Botanical Garden Press, St. Louis, pp. 80-84.

DALSTRÖM S., GYELTSHEN N., GYELTSHEN C., HOIJER T. \& J. WANGDI 2013. Orchids of Bhutan II: To be or not to be a Chamaegastrodia. Orchids 87 (3): 150-153.

GAGNEPAIN F. 1932. Huit Genres Noveaux D’Orchidées Indochinoises. Bulletin du Museium National d'Histoire Naturelle sér. 2, 4: 591-601.

GAGNEPAIN F. 1934. Orchidaceae. In: LECOMTE P.H. (ed.), Flore Générale de l'Indo-, Volume 6. Masson \& Co., Paris. pp . 142-647.

GOVAERTS R., BERNET P., KRATOCHVIL K., GERLACH G., CARR G., ALRICH P., PRIDGEON A.M., PFAHL J., CAMPACCI M.A., BAPTISTA D.H., TIGGES H., SHAW J., CRIBB P.J., GEORGE A., KREUTZ K. \& J.J. WOOD 2021. World checklist of Orchidaceae. The Board of Trustees of the Royal Botanic Gardens, Kew. Available at: http://wcsp.science.kew. org/home.do (Accessed on 04.09.2021)

IUCN 2019. Guidelines for using the IUCN Red List categories and criteria, version 3.1, second edition. Available at: http://www.iucnredlist.org/documents/ RedListGuidelines.pdf. (Accessed on 12.04.2019).

JACQUEMYN H., WAUD M., MERCKX V.S.F.T., BRYS R., TYTECA D., HEDRÉN M. \& B. LIEVENS 2016. Habitat-driven variation in mycorrhizal communities in the terrestrial orchid genus Dactylorhiza. Scientific Reports 6: 37182. https://doi.org/10.1038/ srep37182

JOSEPH J. \& N.R. ABBAREDDY. 1985. Evrardia asraoa Joseph et Abbareddy - a new orchid species from Khasi Hills, Meghalaya, with incidental first record of the genus from India. Bulletin of Botanical Survey of India 25 (1-4): 232-234.

MAEKAWA F. 1935. Dua genera nova orchidacearum Japonensium. Botanical Magazine (Tokyo) 49: 596-599.

ORMEROD P. 2002. Taxonomic changes in Goodyerinae (Orchidaceae: Orchidoideae). Lindleyana 17: 189-238.

PRIDGEON A.M., CRIBB P.J., CHASE M.W. \& F.N. RASMUSSEN 2003. Genera Orchidacearum 3, Orchidoideae (Part 2), Vanilloideae. Oxford University Press, Oxford.

RAUSCHERT E. 1983. Beitrag zur Nomenclatur der Orchidaceae. Fedde Repertorium 94 (7-8): 433-471. 
SEIDENFADEN G. 1978. Orchid genera in Thailand VI. Neottiodeae Lindl. Dansk Botanisk Arkiv 32 (2): 1-195.

SEIDENFADEN G. 1994. The genus Chamaegastrodia

(Orchidaceae). Nordic Journal of Botany 14 (3): 293-301.

SWAMI N. 2016. Terrestrial Orchids. Naresh Swami.

SWAMI N. 2017. Orchids of Ziro Arunachal Pradesh. Naresh Swami.

TANG T. \& F.T. WANG 1951. On the identity of eight
Gagnepain's Orchidaceae genera from Indo China. Acta Scientifica Sinica 2(3): 312-322.

XU Z., JIANG H., YE D. \& E. LIU 2011. The wild Orchids of Yunnan. Yunnan Publishing Group and Yunnan Science \& Technology Press, China.

YANG C.K., YEH H.T., LEOU C.S. \& Y.N. WANG 2014. Odontochilus poilanei (Gagnep.) Ormerod (Orchidaceae), a newly recorded species in Taiwan. Taiwan Journal of Forestry Science 29 (1): 79-84. 